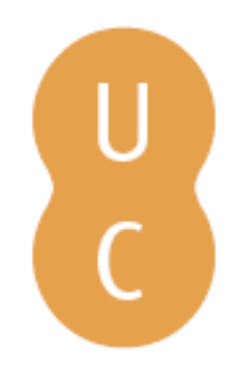

\title{
nombalina
}

\section{IPSAS: history - spread - use}

Autor(es): $\quad$ Schmidthuber, Lisa; Hilgers, Dennis

Publicado por: Imprensa da Universidade de Coimbra

URL

persistente:

URI:http://hdl.handle.net/10316.2/47452

DOI:

DOI:https://doi.org/10.14195/978-989-26-1861-6_7

Accessed : $\quad$ 26-Apr-2023 14:57:27

A navegação consulta e descarregamento dos títulos inseridos nas Bibliotecas Digitais UC Digitalis, UC Pombalina e UC Impactum, pressupõem a aceitação plena e sem reservas dos Termos e Condições de Uso destas Bibliotecas Digitais, disponíveis em https://digitalis.uc.pt/pt-pt/termos.

Conforme exposto nos referidos Termos e Condições de Uso, o descarregamento de títulos de acesso restrito requer uma licença válida de autorização devendo o utilizador aceder ao(s) documento(s) a partir de um endereço de IP da instituição detentora da supramencionada licença.

Ao utilizador é apenas permitido o descarregamento para uso pessoal, pelo que o emprego do(s) título(s) descarregado(s) para outro fim, designadamente comercial, carece de autorização do respetivo autor ou editor da obra.

Na medida em que todas as obras da UC Digitalis se encontram protegidas pelo Código do Direito de Autor e Direitos Conexos e demais legislação aplicável, toda a cópia, parcial ou total, deste documento, nos casos em que é legalmente admitida, deverá conter ou fazer-se acompanhar por este aviso.

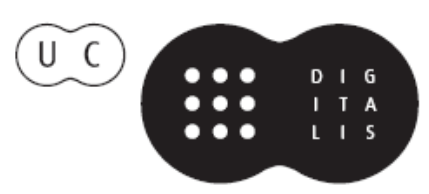



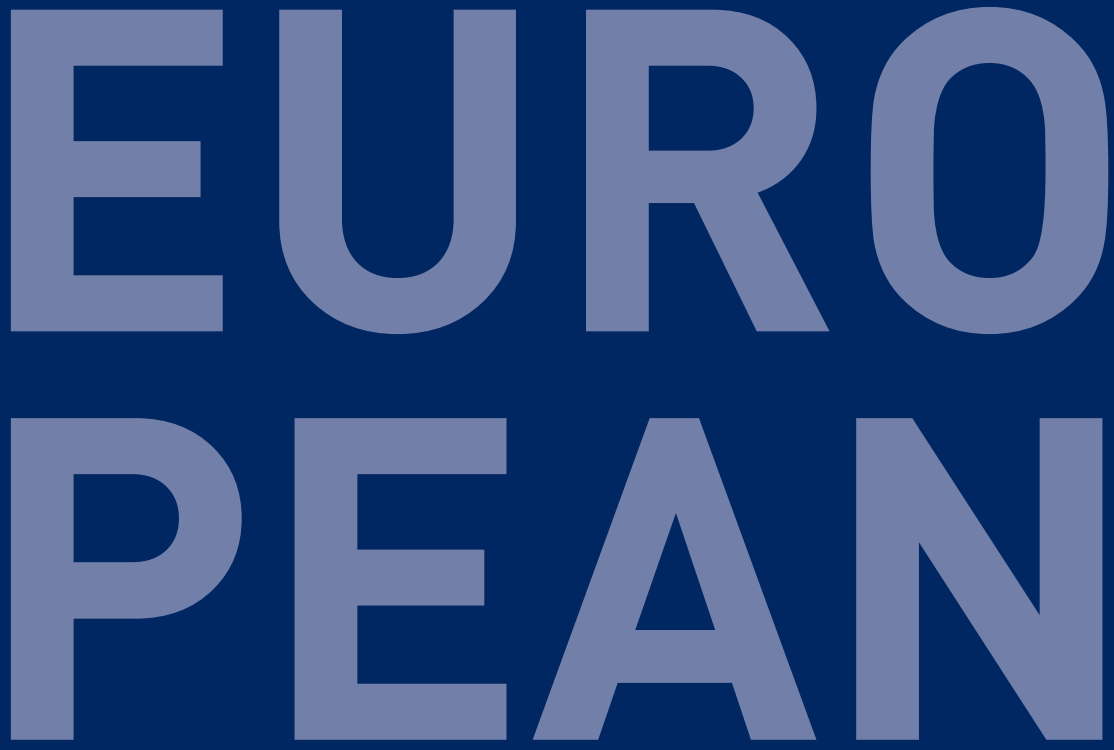

\section{PUBLIC SECTOR ACCOUNTING}

PETER C. LORSON SUSANA JORGE ELLEN HAUSTEIN

(EDS.) 


\title{
CHA P T E R 7 \\ IPSAS: HISTORY - SPREAD - USE
}

\author{
Lisa Schmidthuber, Dennis Hilgers \\ Johannes Kepler University Linz, Austria \\ lisa.schmidthuber@jku.at \\ bttps://orcid.org/0000-0002-0349-9965 \\ dennis.hilgers@jku.at \\ bttps://orcid.org/0000-0003-2660-7057
}

SUMMARY

A great diversity of accounting and financial reporting methods challenge the comparison of financial information among countries or across government levels in the public sector. In striving for transparency and accountability, International Public Sector Accounting Standards, shortly IPSAS, aim to provide an accurate and fair view of financial positions, financial performance and cash flows. The IPSAS are developed by the IPSAS Board (IPSASB) with the aim of improving the quality of financial reporting at a global level and providing comparable financial information. By now, the international standard-setting Board has developed 42 accrual-based standards and one cash-based standard. Approximately 80 countries and organisations apply IPSAS, however, to different extents. IPSAS can be implemented either directly or indirectly through national standards. As the first of four chapters about IPSAS in this book, this chapter aims to give an introduction to IPSAS by describing the history of IPSAS and elaborating on its spread and use. Two case examples are provided to illustrate the implementation process of IPSAS. First, Austria has implemented IPSAS-like accrual accounting. Second, Germany does not apply IPSAS so that the reasons for refusing to adopt IPSAS are outlined. Finally, findings from empirical studies on IPSAS are summarised.

\section{KEYWORDS}

IPSAS, international accounting, accounting harmonisation 


\section{Introduction}

In recent years, traditional cash-based accounting systems have been moved towards accrual-based accounting systems with the aim of providing more accurate information about the financial situation of a public entity and of increasing transparency and accountability. ${ }^{1}$ Next to providing a true and fair view of the financial situation, the assets and the revenues, financial statements should be comparable to other countries and other government levels. This requires international accounting harmonisation. The International Public Sector Accounting Standards (IPSAS) are developed with the aim of harmonising public sector accounting (PSA) at the international level.

Therefore, this section focuses on IPSAS and it has the followings aims:

- Providing an overview on the evolution of the IPSAS and the role of the IPSASB in the development of international comparable PSA standards.

- Describing what are IPSAS, which benefits are associated with the use of IPSAS, and which countries and organisations have adopted IPSAS.

- Explaining the implementation process of IPSAS and illustrating the implementation process by providing a case example.

The chapter is structured as follows: Section 2 illustrates the evolution of international harmonisation of PSA standards and focuses on the institutions responsible for the development of IPSAS. In Section 3, IPSAS are described in detail and the benefits of adoption are discussed. Section 4 concentrates on the spread of IPSAS and refers to the accounting practices of European countries. Section 5 gives an overview on the implementation process of IPSAS by distinguishing the section-specific and the sector-neutral approach. Section 6 illustrates the implementation process of IPSAS by the Austrian case example and gives reasons for refusing to implement IPSAS by

1 IFAC/CIPFA (2018), pp. 2-5. 
referring to the German case example. Section 7 summarises findings from empirical research on IPSAS. Section 8 concludes by discussing the benefits and challenges of IPSAS.

Further chapters in this textbook continue the explanations on IPSAS by addressing the IPSASB Conceptual Framework (Chapter 8), the IPSAS concept of General Purpose Finanical Reporting (Chapter 9), selected public sector specific IPSAS (Chapter 10) and an IPSAS case study (Chapter 11).

\section{Evolution of IPSAS}

The IPSAS are developed by the International Public Sector Accounting Standards Board, shortly IPSASB. The strategic objective of the IPSASB is to enhance public financial management and knowledge on a global level by increasing the adoption of accrual-based IPSAS. The Board intends to achieve this aim by developing high-quality public sector financial reporting standards, publishing practice guidelines and studies, and raising awareness of IPSAS and the benefits of their adoption. The IPSASB consists of 18 members and includes representatives from ministries of finance, government audit institutions, public practice and academia. 15 out of 18 members are nominated by the Board of IFAC, and the remaining three members are appointed as public members. Membership is usually for three years, and can be renewed for a further three-year term. ${ }^{2}$

The IPSASB is supported by the International Federation of Accountants (IFAC). Originally, the IFAC, which was established in 1977 in New York with the idea of supporting international harmonisation of accounting, has launched a Public Sector Committee, shortly PSC, in 1986. This committee was intended to publish studies and research papers on PSA. In 1996, the so-called 'Standards Project' that aims for formulating and issuing the IPSAS was established. Finally, in 2004, the Public Sector Committee has changed the name to IPSASB.

\footnotetext{
2 IPSASB (2016).
} 
The purposes of the IPSASB are manifold. First, the IPSASB aims at developing high-quality accounting standards for use in public sector entities. Second, in accordance with the mission of IFAC, it intends to enhance the quality of the public financial reporting on a global level. Third, the IPSASB aims at improving the financial engineering and reporting of public entities. Finally, it plans a convergence of national and international public standards of accounting.

Since 1997, the IPSASB has developed 42 IPSAS, three Recommended Practice Guidelines (RPG), an IPSAS standard for reporting under the cash basis of accounting, and a conceptual framework. The next paragraph describes the IPSAS in more detail.

\section{IPSAS: Concept and Overview}

The International Public Sector Accounting Standards, shortly IPSAS, are a set of mainly accrual-based standards that should provide a uniform global basis for the preparation of annual financial statements in the public sector. IPSAS are based on the International Financial Reporting Standards, shortly IFRS, that are mainly used in the private sector. Although IPSAS are based on IFRS, there are some differences between the accounting standards. First, the terminology and references have to be adapted to characteristics of the public sector. Second, the convergence of IPSAS with IFRS is limited, as there are no IFRS standards available for specific requirements of the public sector as addressed in more detail in Chapters 10 and 11. For example, in the public sector, there are special kinds of transactions that do not exist in the private sector (e.g., income from taxes, transfer between public sector entitics). This reminds us of great differences between private sector and public sector accounting, which are highlighted in Chapter 3.

The application of IPSAS is expected to have various benefits:

\section{- Monitoring of government debt and liabilities for their economic} implications: The introduction of IPSAS intends to reduce economic uncertainties and significant threats posed by inappropriately managed debt. A full disclosure of all assets, liabilities and contingent 
liabilities is vital for assessing the true economic implications of public sector financial management. The disclosure of liabilities might encourage government leaders to make decisions that focus on longterm sustainability. For example, this refers to the disclosure of longterm obligations of government such as pension obligations.

- Transparency and accountability in public sector finances: In accordance with the idea of IPSAS, governments have to provide accurate and complete information on expenditures and transactions. This information focuses on both short-term and long-term impacts of decision making. Transparent financial reporting can improve public sector decision making and make governments more accountable to their citizens.

- Enhancing citizen trust in government: The application of IPSAS also influences citizen-government relation, as citizens are affected by government's financial management decisions. Transparent financial reporting thus can help governments to regain or increase citizen trust in government.

Currently, the IPSAS encompass 42 accrual-based standards and one cash-based standard. Table 7.1 gives an overview on the individual standards and relates them with the IFRS. Once more, it becomes evident that IFRS cannot be simply translated to IPSAS. Instead, the characteristics of public sector accounting have to be taken into account. For example, there are no corresponding IFRS to IPSAS 22, IPSAS 23, IPSAS 24 and for the Cash Basis IPSAS.

\begin{tabular}{|l|l|l|}
\hline IPSAS & Title & Corresponding IFRS \\
\hline IPSAS 1 & Presentation of Financial Statements & IAS 1 \\
\hline IPSAS 2 & Cash Flow Statements & IAS 7 \\
\hline IPSAS 3 & $\begin{array}{l}\text { Accounting Policies, Changes in Accounting } \\
\text { Estimates and Errors }\end{array}$ & IAS 8 \\
\hline IPSAS 4 & The Effects of Changes in Foreign Exchange Rates & IAS 21 \\
\hline IPSAS 5 & Borrowing Costs & IAS 23 \\
\hline IPSAS 6 & $\begin{array}{l}\text { Consolidated and Separate Financial Statements } \\
\text { (superseded by IPSASs 34-38) }\end{array}$ & IAS 27 \\
\hline IPSAS 7 & $\begin{array}{l}\text { Investments in Associates (superseded by IPSASs } \\
34-38)\end{array}$ & IAS 28 \\
\hline IPSAS 8 & $\begin{array}{l}\text { Interests in Joint Ventures (superseded by IPSASs } \\
34-38)\end{array}$ & IAS 31 \\
\hline
\end{tabular}




\begin{tabular}{|c|c|c|}
\hline IPSAS 9 & Revenue from Exchange Transactions & IAS 18 \\
\hline IPSAS 10 & Financial Reporting in Hyperinflationary Economies & IAS 29 \\
\hline IPSAS 11 & Construction Contracts & IAS 11 \\
\hline IPSAS 12 & Inventories & IAS 2 \\
\hline IPSAS 13 & Leases & IAS 17 \\
\hline IPSAS 14 & Events After the Reporting Date & IAS 10 \\
\hline IPSAS 15 & $\begin{array}{l}\text { Financial Instruments: Disclosure and Presentation } \\
\text { (superseded by IPSASs 28-30) }\end{array}$ & IAS 32 \\
\hline IPSAS 16 & Investment Property & IAS 40 \\
\hline IPSAS 17 & Property, Plant and Equipment & IAS 16 \\
\hline IPSAS 18 & Segment Reporting & IAS 14 \\
\hline IPSAS 19 & $\begin{array}{l}\text { Provisions, Contingent Liabilities and Contingent } \\
\text { Assets }\end{array}$ & IAS 37 \\
\hline IPSAS 20 & Related Party Disclosures & IAS 24 \\
\hline IPSAS 21 & Impairment of Non-Cash-Generating Assets & $\begin{array}{l}\text { No directly } \\
\text { corresponding IFRS }\end{array}$ \\
\hline IPSAS 22 & $\begin{array}{l}\text { Disclosure of Financial Information about the } \\
\text { General Government Sector }\end{array}$ & No corresponding IFRS \\
\hline IPSAS 23 & $\begin{array}{l}\text { Revenue from Non-Exchange Transactions (Taxes } \\
\text { and Transfers) }\end{array}$ & No corresponding IFRS \\
\hline IPSAS 24 & $\begin{array}{l}\text { Presentation of Budget Information in Financial } \\
\text { Statements }\end{array}$ & No corresponding IFRS \\
\hline IPSAS 25 & Employee Benefits (will be superseded by IPSAS 39 & IAS 19 \\
\hline IPSAS 26 & Impairment of Cash-Generating Assets & IAS 36 \\
\hline IPSAS 27 & Agriculture & IAS 41 \\
\hline IPSAS 28 & Financial Instruments: Presentation & IAS 32/IFRIC 2 \\
\hline IPSAS 29 & $\begin{array}{l}\text { Financial Instruments: Recognition and } \\
\text { Measurement }\end{array}$ & IAS 39/IFRIC 9/IFRIC 16 \\
\hline IPSAS 30 & Financial Instruments: Disclosure & IFRS 7 \\
\hline IPSAS 31 & Intangible Assets & IAS 38/SIC 32 \\
\hline IPSAS 32 & Service Concession Arrangements - Grantor & Mirror to SIC 12 \\
\hline IPSAS 33 & First-time Adoption of Accrual Basis IPSASs & (IFRS 1) \\
\hline IPSAS 34 & Separate Financial Statements & IAS 27 (amended 2011) \\
\hline IPSAS 35 & Consolidated Financial Statements & IFRS 10 \\
\hline IPSAS 36 & Investments in Associates and Joint Venture & IAS 28 (amended 2011) \\
\hline IPSAS 37 & Joint Arrangements & IFRS 11 \\
\hline IPSAS 38 & Disclosure of Interests in Other Entities & IFRS 12 \\
\hline IPSAS 39 & Employee Benefits & IAS 19 (issued 2011) \\
\hline IPSAS 40 & Public Sector Combinations & (IFRS 3) \\
\hline IPSAS 41 & Financial Instruments & IFRS 9 \\
\hline IPSAS 42 & Social Benefits & No corresponding IFRS \\
\hline $\begin{array}{l}\text { Cash Basis } \\
\text { IPSAS }\end{array}$ & Cash Flow Statement & No corresponding IFRS \\
\hline
\end{tabular}

Table 7.1: Overview on IPSAS

Source: Müller-Marqués Berger (2018), Deloitte (2019). 


\section{Spread of IPSAS: Who is using IPSAS?}

The aim of developing the IPSAS was to provide a standard for accounting practices in public sector entities on a global level. Accordingly, the IPSASB is aiming for an international use of IPSAS. Currently, approximately 80 countries and several international organisations apply IPSAS. In terms of application of standards, different compliance levels have to be considered. Whereas some organisations fully apply IPSAS, which means that they make use of all the 42 standards, others only partly apply the standards (i.e. pick single standards or they are applied in a modified way). In addition, various countries align their national accounting standards to IPSAS, however, to different degrees. Furthermore, the application of IPSAS can differ among government levels (i.e. the central, state and local level).

In general, we can observe an international trend towards accrual accounting, which is in line with the visions of the IPSASB. Table 7.2 gives an overview on current accounting practices of European countries. As illustrated in the table, numerous countries apply accrual accounting and various countries use IPSAS as a basis (e.g., Austria, Estonia, and Lithuania). Furthermore, several European countries are using modified cash accounting (e.g., Greece, Italy, and Slovenia). Finally, some countries like the Netherlands are in a process of transittening to accrual accounting only recently.

Next to differences in accounting practices among countries, there are intra-country variations when it comes to accounting. For example, Austria applies IPSAS at the central level. However, currently, the state and local government level do not apply accrual accounting but cash accounting. As far as Germany is concerned, cash accounting is applied at the central level. To the contrary, local governments mainly apply accrual accounting. In summary, there are still great differences in accounting practices among countries and government levels. 


\begin{tabular}{|c|c|c|c|c|c|c|}
\hline \multirow{2}{*}{ Country } & \multicolumn{2}{|c|}{ Accrual accounting } & \multicolumn{2}{|c|}{ Modified cash accounting } & \multicolumn{2}{|c|}{ Cash accounting } \\
\hline & IPSAS/ IFRS & Other & IPSAS/ IFRS & Other & IPSAS/ IFRS & Other \\
\hline Austria & $\mathrm{x}$ & & & & & \\
\hline Belgium & & $\mathrm{x}$ & & & & \\
\hline Bosnia & & & $\mathrm{x}$ & & & \\
\hline Bulgaria & & & & & & $\mathrm{x}$ \\
\hline Czech Republic & & & $\mathrm{x}$ & & & \\
\hline Denmark & & $\mathrm{x}$ & & & & \\
\hline Estonia & $\mathrm{x}$ & & & & & \\
\hline Finland & & $\mathrm{x}$ & & & & \\
\hline France & & $\mathrm{x}$ & & & & \\
\hline Germany & & & & & & $\mathrm{x}$ \\
\hline Greece & & & & $\mathrm{x}$ & & \\
\hline Hungary & & & & $\mathrm{x}$ & & \\
\hline Iceland & & & & $\mathrm{x}$ & & \\
\hline Ireland & & & & & & $\mathrm{x}$ \\
\hline Italy & & & & $\mathrm{x}$ & & \\
\hline \multicolumn{7}{|l|}{ Kosovo } \\
\hline Lithuania & $\mathrm{x}$ & & & & & \\
\hline Luxembourg & & & & & & $\mathrm{x}$ \\
\hline The Netherlands & & & & & & $\mathrm{x}$ \\
\hline Macedonia & & & & & & $\mathrm{x}$ \\
\hline Moldavia & & $\mathrm{x}$ & & & & \\
\hline Poland & & & & $\mathrm{x}$ & & \\
\hline Portugal & $\mathrm{x}$ & & & & & \\
\hline Romania & & & & $\mathrm{x}$ & & \\
\hline Serbia & & & & & $\mathrm{x}$ & \\
\hline Slovakia & & & $\mathrm{x}$ & & & \\
\hline Slovenia & & & & $\mathrm{x}$ & & \\
\hline Spain & $\mathrm{x}$ & & & & & \\
\hline Sweden & $\mathrm{x}$ & & & & & \\
\hline Switzerland & $\mathrm{x}$ & & & & & \\
\hline Turkey & $\mathrm{x}$ & & & & & \\
\hline Ukraine & & & & $\mathrm{x}$ & & \\
\hline United Kingdom & $\mathrm{x}$ & & & & & \\
\hline
\end{tabular}

Table 7.2: Accounting Practices of European Countries: Current financial reporting basis and financial reporting framework

Source: IFAC/CIPFA (2018): 2018 Status Report

Notes: "IPSAS/IFRS" for countries that are directly or indirectly adopting IPSAS/IFRS or at least using IPSAS/IFRS as a reference point. No data available for Albania,

Croatia, Kosovo, Latvia and Norway 
With regard to developing countries, most African countries apply cash accounting practices, whereas numerous Asian and Latin American countries plan an IPSAS reform. ${ }^{3}$ For developing countries, the implementation of IPSAS is of high importance, as institutions such as the World Bank require govermments to implement IPSAS in return for financial support. In contrast, developed countries have already implemented national accounting standards, and thus have lower ambitions to implement IPSAS ${ }^{4}$. While many developing countries such as Kenya or Madagascar have still not adapted to IPSAS, there are others, for example, Uganda, which have already implemented IPSAS. It should be noted that the adoption of IPSAS means to undergo a fundamental and expensive change in financial administration and culture, which especially for developing countries can be a challenge. The question about how IPSAS can be implemented by a country is answered in the next section.

\section{Implementation process of IPSAS}

As already outlined, there is an international trend towards accrual accounting, although there are also other views as discussed in Chapter 2. However, accrual accounting is not equitable to applying IPSAS, and there are numerous reasons why to link accrual accounting legislation to IPSAS:

- Enhancing comparability of financial information among countries, across government levels, and being in accordance with international organisations (e.g. European Commission, OECD).

- Improving comparability of financial information between the public and private sector.

- Facilitating the consolidation of financial statements.

- Making use of the knowledge accumulated by the IPSASB.

\footnotetext{
3 Christiaens et al. (2015).

4 Chan (2006), p. 6.
} 
When it comes to implementing IPSAS, countries can either directly adopt them or adopt them through national standards. First, most international organisations such as the OECD, IMF, UN or NATO have implemented IPSAS directly. The implementation of IPSAS means changing an existing law (e.g. law on public sector financial reporting), and taking IPSAS as a legal basis. Although the IPSASB encourages full endorsement of IPSAS in order to ensure comparability, countries also partially adopt IPSAS. For example, Switzerland has implemented IPSAS on the federal level, while the extent of implementation on the cantonal level varies. Second, IPSAS can be adopted through national standards - the implementation method most countries choose. Adoption through national standards means that IPSAS act as a basis for national standards and country-specific adaptions such as terms and definitions are made. There are two main approaches on how to adopt IPSAS through national standards: ${ }^{5}$

Sector-specific approach: In terms of the sector-specific approach, a separate set of national standards is used by the public sector. In particular, large countries such as the USA, Canada or South Africa make advantage of this approach due to various benefits:

- Specific aspects of governmental accounting will be observed (e.g. non-exchange transactions, non-cash generating assets).

- Opportunity to make adaptations to each jurisdiction's needs.

- Facilitate the implementation of international standards.

Still, on the contrary, this approach needs a high level of coordination effort.

Sector-neutral approach: With respect to the sector-neutral approach, there is only one set of national standards for application in both the private and public sector. This approach is thus also called "transaction neutral", and is applied in e.g. Australia and New Zealand. The central advantages of this approach are as follows:

5 Bergmann (2009), pp. 110-112. 
- Enhanced comparability and understandability of financial information.

- Mobility of the workforce involved.

- Efficiency in standard-setting.

- High quality of standards.

In spite of these benefits, the approach is known for a highly complex standard-setting process. Furthermore, non-financial aspects and specificities of PSA might be neglected due to the sector-neutral standards.

\section{IPSAS implementation: Case examples}

To illustrate the implementation process in more detail, two case examples are provided in the following. First, the change in the accounting system in Austria is described as a country where IPSAS have been implemented. Second, the arguments of a country refusing to implement IPSAS are outlined by referring to Germany.

Austria has decided to adapt the public sector accounting system and change toward an accrual accounting system in the $2000 \mathrm{~s}^{6}$. In aiming for better information for budget decision making, an indirect approach to implement IPSAS was chosen. Although a full compliance with the IPSAS was not intended, they were considered as a reference point. Austria applies 20 IPSAS fully, five partially, and does not apply 7 out of the then 32 standards. ${ }^{7}$ National standards were prepared directly by the Ministry of Finance, and the legal drafts of the standards were finalised in cooperation with the Court of Audits.

Austria adapted the accounting system to IPSAS basis in a two-step reform process (see Figure 7.1), whereas the IPSAS adoption was only one part of an overall reform that also addressed budgeting: In 2009, a mediumterm expenditure framework with legally binding expenditure ceilings

\footnotetext{
6 Schauer (2016).

7 OECD/IFAC (2017).
} 
for the next four years was developed, and ministries got more flexibility through the possibility to create financial reserves without appropriation. This means that funds that are left at the end of the year can be taken into the next year.

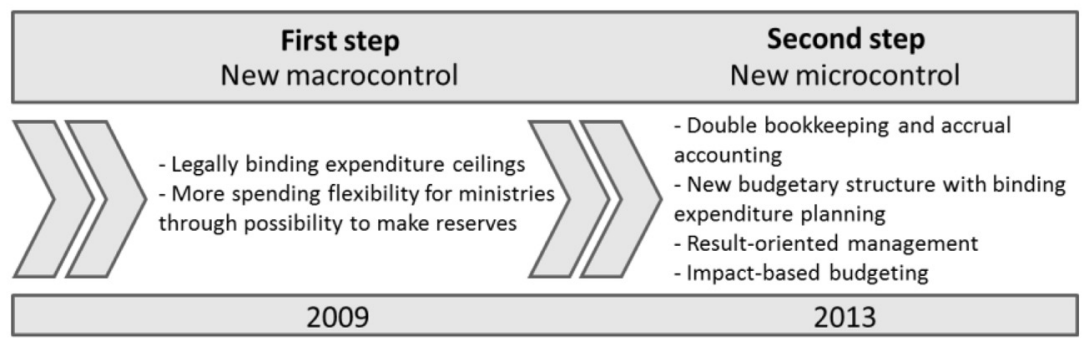

Figure 7.1: Austria - Two-step reform process

In 2013, the accounting system was adjusted to double-entry bookkeeping and accrual accounting. In addition, a new budgetary structure with binding expenditure planning was implemented. With the 2013 reform, outcome-oriented management and performance budgeting became core principles of Austrian financial administration. In practice, this means that the Austrian budget has been divided into categories, subcategories, global budgets and detail budgets. The division into categories, subcategories and global budgets is based on affairs (topic-oriented), while the division into detail budgets is based on the administrative departments. The expenditure planning for the total budget, the categories, the subcategories and the global budgets is set by law, while the detail budgets are binding for internal administrative processes. ${ }^{8}$

Contrary to Austria, Germany is still reluctant to implement accrual accounting in general and IPSAS in particular, at least at the central level. Similar to Austria, Germany is a federal state so that three government levels have to be distinghuished (i.e. central, state and local). As explained in section 4, there are differences between government levels in terms of accounting. This means that governmental accounting is not comparable across German government levels. Consequently, harmonisation of

8 Schauer (2016). 
governmental accounting at federal and central state levels has been intended from 2010 onwards. However, the implementation of accrual accounting is challenging, as the Finance and Personnel Statistics Law requires cash-based information. States with accrual accounting systems thus have to report cash basis information for finance statistics purposes also. Currently, only three federal state governments (i.e. Bremen, Hamburg and Hessen) have implemented accrual-based accounting systems so far. ${ }^{9}$

Another reason for Germany's reluctance are high costs associated with the implementation of IPSAS (expected up to 2.3 billion Euro). ${ }^{10}$ Besides that, it is being criticised that IPSAS are not suitable for key functions of public sector accounting, for example, taxing and social welfare, and that they are too complex. German officials also question whether it makes sense to assess the value of unsaleable assets like streets or pedestrian ways. ${ }^{11}$ Supporters of IPSAS are worried about Germany's restraint, as they argue that a powerful country like Germany could be a role model for other countries to implement IPSAS.

\section{Empirical Studies on IPSAS adoption}

A number of scholars have already investigated the emergence of international accounting harmonisation in the public sector. First, there are various papers having investigated why governments or organisations decide to adopt IPSAS. Referring to European countries, studies found that a government's decision to adopt IPSAS is influenced by a desire for bigh-quality financial information. For example, an international survey among accounting officials from American and European countries found that governments decide to adopt IPSAS due to international comparability and improved quality of financial reporting systems. ${ }^{12}$ Findings from

\footnotetext{
9 Müller-Marqués Berger and Heiling (2015).

10 KPMG (2019).

11 Deloitte (2012).

12 Brusca and Martínez (2016).
} 
another multi-country study indicate that accounting experts appreciate the facilitation of the consolidation of financial statements. ${ }^{13}$

Scholars have also examined why governments refuse to adopt IPSAS. Antipova and Bourmistrov (2013) explain a lack of accounting harmonisation by path dependency in accounting tradition. According to Oulasvirta (2014), Finland does not apply IPSAS due to a lack of pressure to change. Findings from Christiaens et al. (2015) indicate that the fear of losing standard-setting authority holds countries back from IPSAS adoption. Costs of implementation and adapting the national accounting standards to IPSAS are a further hampering factor. ${ }^{14}$

Second, studies have examined the effectiveness of IPSAS adoption. Based on survey data from 29 National Accounting Standard Setters (NASS) in Continental European, Anglo-American and Scandinavian countries, Bolívar and Galera (2016) conclude that fair value accounting (FVA) increases the usefulness of government financial statements for information users. Although the adoption of FVA is associated with higher costs, it improves government financial statements in terms of understandability, transparency, and accountability. In terms of harmonisation of public sector accounting in the EU, Pontoppidan and Brusca (2016) found that, instead of international accounting harmonisation, EU member states are prone to regional governance, meaning that European Public Sector Accounting Standards (EPSAS) are developed (for more details please see Chapter 14).

\section{Conclusion}

With the aim of harmonising public sector accounting at a global level, the IPSASB has been developing International Public Sector Accounting Standards, shortly IPSAS, from 2004 onwards. The application of a common set of public sector accounting standards by public sector entities

\footnotetext{
13 Christiaens et al. (2015).

14 Brusca and Martínez (2016).
} 
aims at implementating an accrual-based accounting system, achieving comparability and consistency of financial information both among countries and across government levels, and improving accounting information for better decision-making. Applying IPSAS is associated with a higher level of transparency in government accounting and financial reporting that in turn positively relates to accountability and oversight control. Due to higher quality of financial information, decision-making processes and assets and liability management is assumed to be improved. Enhanced government financial statistical information further benefits the recognition of risks, opportunities, cost awareness and efficiency.

Next to various benefits associated with the evolution of a common set of public sector accounting standards at a global level, numerous challenges should not be neglected. Implementing IPSAS is associated with an organisational change so that innovation barriers such as negative attitudes toward change (e.g., resistance to change), a lack of tangible resources including IT platforms or financial capacities, and insufficient task knowledge and experience on how to implement a new accounting system can challenge a successful adoption. Nevertheless, international reporting on basis of IPSAS provides an opportunity to increase the quality of financial reporting results, enhance international comparability and improve decision making by government.

\section{Bibliographic references}

ANTIPOVA, Tatjana and BOURMISTROV, Anatoli (2013) - Is Russian public sector accounting in the process of modernization? An analysis of accounting reforms in Russia. Financial Accountability \& Management, 29(4), 442-478.

BRUSCA, Isabel and MARTÍNEZ, Juan Carlos (2016) - Adopting International Public Sector Accounting Standards: a challenge for modernizing and harmonizing public sector accounting. International Review of Administrative Sciences, 82(4), 724-744.

CHRISTIAENS; Johan, VANHEE, Christophe; MANES-ROSSI, Francesca, AVERSANO, Natalia and VAN CAUWENBERGE, Philippe (2015) - The effect of IPSAS on reforming governmental financial reporting: An international comparison. International Review of Administrative Sciences, 81(1), 158-177.

DELOITTE (2019) - IASPlus, International Public Sector Accounting Standards (IPSAS). https://www.iasplus.com/en/standards/ipsas (accessed 05/02/2019) 
DELOITTE (2012) - IASPlus, Results of the Eurostat consultation on the suitability of IPSAS for the EU Member States. https://www.iasplus.com/en/news/2012/december/ipsas-inthe-eu (accessed 23/05/2019)

IFAC/CIPFA (2018) - International Public Sector Financial Accountability Index: Status Report. Retrieved from https://www.ifac.org/system/files/publications/files/IFAC-CIPFAPublic-Sector-Index-2018-Status.pdf. (accessed 29/01/2019)

IPSASB (2016): International Public Sector Accounting Standards Board: Fact Sheet, June 2016. Retrieved from https://www.ifac.org/system/files/uploads/IPSASB/IPSASB-FactSheet-June-2016-2.pdf (accessed 13/05/2019)

KPMG (2019) - Deutschland muss bei EPSAS-Einführung mit den höchsten Kosten rechnen. https://publicgovernance.de/html/de/3720.htm (accessed 29/01/2019)

MÜLLER-MARQUÉS BERGER, Thomas \& HEILING, Jens (2015) - Public Sector Accounting and Auditing in Germany. In Brusca, I., CAPERCHIONE, E., COHEN, S. and F. ManesRossi (eds.): Public Sector Accounting and Auditing in Europe (pp. 93-107). Palgrave Macmillan, London.

MÜLLER-MARQUÉS BERGER, Thomas - IPSAS Explained: A Summary of International Public Sector Accounting Standards, 2018, Chichester: Wiley, ISBN: 978-1-119-41506-0. 3rd ed.

OULASVIRTA, Lasse (2014) - The reluctance of a developed country to choose International Public Sector Accounting Standards of the IFAC. A critical case study. Critical Perspectives on Accounting, 25(3), 272-285.

PONTOPPIDAN, Caroline and BRUSCA, Isabel (2016) - The first steps towards harmonizing public sector accounting for European Union member states: strategies and perspectives. Public Money \& Management, 36(3), 181-188.

RODRÍGUEZ BOlíVAR, Manuel Pedro, NAVARRo GALERA, Andres, ALCAIDE MUÑOZ, Laura, \& LÓPEZ SUBIRÉS, Maria Deseada (2016) - Risk factors and drivers of financial sustainability in local government: An empirical study. Local Government Studies, 42(1), 29-51.

SCHAUER, Reinbert (2016) - Rechnungswesen in öffentlichen Verwaltungen. $3^{\text {rd }}$ edition. Linde.

SVOBODA, Michal (2016) - Modernisation of Public Sector Financial Reporting Systems in Europe - Challenges and Milestones. European Financial and Accounting Journal, University of Economics, Prague, 4, 05-16.

\section{Additional readings}

BERGMANN, Andreas - Public Sector Financial Management, 2009, Harlow et al.: Prentice Hall, ISBN: 978-0-273-71354-8.

BRUSCA, Isabel; CAPERCHIONE, Eugenio; COHEN, Sandra and MANES-ROSSI, Francesca (eds.) - Public Sector Accounting and Auditing in Europe - the Challenge of Harmonization, 2015, Basingstoke: Palgrave Macmillan, ISBN: 978-1-137-46133-9

MANES ROSSI, Francesca; CAPERCHIONE, Eugenio; COHEN, Sandra, and BRUSCA, Isabel (2019) - Financial Management and Public Sector Accounting in an Age of Reforms: Developments and Changes in Public Sector Financial Management. In ONGARO, Edoardo (ed.): Public Administration in Europe (pp. 235-246). Palgrave Macmillan, Cham.

ONGARO, Edoardo, \& VAN THIEL, Sandra (Eds.) (2018) - The Palgrave handbook of public administration and management in Europe. Palgrave Macmillan.

SCHUMESCH, Patrice, DE LAET, Jan, \& DE GREEF, Anton (2012) - IPSAS in a nutshell-from principles to practice. PwC. 


\section{Discussion topics}

- What is the nature of the harmonisation of accrual accounting?

- What are the benefits of IPSAS?

- How to cope with organisational reluctance in applying IPSAS? 